\title{
Nazewnictwo stosunków rodzinnych w świetle praktyki sądów sieradzkich w 15. wieku*
}

\section{Die Namenkunde der Familienverhältnisse angesichts der Praxis der Sieradzer-Gerichte im 15. Jhr.}

1. Rola studiów nad terminologią krewniaczą. 2. Charakterystyka zapisów zawierających informacje o więzach rodzinnych. 3. Znaczenie występujących $w$ księgach terminów. 4. Zestawienie omówionych $\mathrm{w}$ artykule terminów pokrewieństwa $\mathrm{i}$ powinowactwa.

1. Die Bedeutung der Studien an der Verwandtschaftsterminologie. 2. Die Charakteristik der Eintragungen, die Informationen über Familienbande beinhalten. 3. Die Bedeutung der in den Büchern auftretenden Termini. 4. Das Verzeichnis der im Artikel besprochenen Verwandtschaftsund Verschwägerungstermini.

Odpowiednie dać rzeczy - slowo Cyprian Kamil Norwid

1. Wagę studiów terminologicznych podnoszono już w literaturze historycznej ${ }^{1}$. Mają one szczególne znaczenie w dziedzinie badań genealogicznych. Wartość osiągniętych wyników zależy bowiem od prawidłowego określenia relacji pomiędzy poszczególnymi osobami w zakresie pokrewieństwa i powinowactwa. Analizę terminologii dotyczącej stosunków rodzinnych przeprowadzil M. Szymczak, który na podstawie bogatego materiału historycznego, literackiego i gwarowego omówił 47 nazw określających pokrewienstwo i 17 wskazujących powinowactwo rodzinne ${ }^{2}$. Ważne spostrzeżenia przyniosły badania M. Koczerskiej. Rozpoznała ona występujące w źródłach średniowiecznych nazwy własne pokrewieństwa do IV. stopnia w linii prostej i do IV., a nawet V., w linii bocznej, oraz nazwy powinowactwa I. stopnia

"Zastosowane skróty AGAD - Archiwum Główne Akt Dawnych; CPH - „Czasopismo Prawno-Historyczne", h - herb(u), KGS - Księgi grodzkie sieradzkie; KZS - Księgi ziemskie sieradzkie; KZSz. - Księgi ziemskie szadkowskie.

1 J. Ma tu szewski, Pulapki średniowiecznej laciny, CPH 1983, t. 35/1, s. 1.

${ }^{2} \mathrm{M}$. Szymczak, Nazwy stopni pokrewieństwa $i$ powinowactwa rodzinnego $w$ historii $i$ dialektach jezyka polskiego, Warszawa 1966. 
w linii prostej i II., niekiedy III., w linii bocznej ${ }^{3}$. Oboje autorzy wskazuja na wieloznaczność terminologiczną, występującą $w$ polskich źródłach średniowiecznych. Wnioski te wynikają przede wszystkim z zestawienia terminów lacińskich $\mathrm{z}$ zachowanymi $\mathrm{w}$ źródłach nazwami polskimi. Jednak przytaczane egzemplifikacje, często wyrwane $\mathrm{z}$ kontekstu, nie zawsze dają prawidłowe wyobrażenie o związkach lączących poszczególne osoby. Materiał z ksiąg sądowych Sieradzkiego, zbierany pod kątem genealogii rodzin szlacheckich, przynosząc generalne potwierdzenie osiągniętych dotychczas wyników, pozwala jednak na poczynienie nowych obserwacji.

2. Krewni $\mathrm{z}$ racji usankcjonowanego przez prawo obyczaju uczestniczyli w wielu czynnościach prawnych - zarówno w sądzie, jak i poza nim. W licznych artykułach statutów Kazimierza Wielkiego powoływani są consanguinei, proximiores, amici $i^{4}$. W praktyce sądów sieradzkich dość rzadko występuje jednakże szczególowy opis relacji genealogicznych łączących strony bądź działające $\mathrm{z}$ ich upoważnienia osoby, czy wreszcie jednaczy, dzielców, poręczycieli. Pisarze podają niekiedy długie listy osób, przeprowadzających ugody poza sądem, ale ich wzajemne powiązania objaśniają sporadycznie. Analiza tych list prowadzi na ogół do wniosku, że są to krewni i powinowaci. Często jednak w tym gronie występują także osoby obce, które ze względu na posiadany w środowisku autorytet, zostały przez strony zaproszone do uczestnictwa.

Dokładny opis związków rodzinnych był konieczny w przypadku powolania się na prawo bliższości w staraniach o sprzedane czy zastawione dobra ${ }^{5}$. Strzegąc praw nabywcy weryfikowano twierdzenia osób występujących $\mathrm{z}$ roszczeniem. Świadczy o tym przypadek Janusza z Dąbrówki i Kościerzyna, którego pretensje do wsi Dzbanki zostały oddalone, gdyż w stosunku do zbywcy okazał się tylko frater clenodialis'.

Drugim rodzajem spraw, w których pojawiają się liczne określenia powiązań rodzinnych, są operacje majątkowe dokonywane przez kobiety. Do połowy XV w. mogły same sprzedawać i zamieniać dobra nieruchome,

${ }^{3}$ M. Koczerska, Uwagi o terminologii pokrewienstwa $i$ powinowactwa $w$ polskich źródlach średniowiecznych, [w:] Genealogia - Problemy metodyczne w badaniach nad polskim spoleczeństwem średniowiecznym na tle porównawczym, red. J. Hertel, Toruń 1982, s. 27-47. W artykule podaje stopnie pokrewieństwa wg komputacji rzymskiej.

4 Statuty Kazimierza Wielkiego, cz. I, wyd. O. Balzer, Poznań 1947, art. 1, 38, 67, 75, 76, 96, 101, 103; cz. II, wyd. L. Lysiak, Warszawa-Poznań 1982, art. 4, 9, 18, 21, 31, 48.

5 W 1485 r. na prawo bliższości do 100 grzywien, zapisanych na 9 łanach we wsi Próchno, powołała się Anna - żona Jana z Trzebini - pozywając Swiętosława z Ostrowa o zajazd w te dobra. Anna argumentował, iż zastawnicy: Jan i Piotr, synowie Jaśka z Sośnicy w Wielkopolsce, są dla niej fratribus ex fratre patrueli germanis - zob. AGAD, KZS, ks. 13, k. 155.

- AGAD, KZS, ks. 12, k. 243-243v. O postępowaniu retrahenta zob. Z. R y m a s z e w s ki, Prawo bliższości krewnych w polskim prawie ziemskim do końca XV w., Wrocław 1970, s. 121-140. 
bez opieki ze strony męża $i$ innych krewnych? . W drugiej połowie tegoż stulecia kobiety występowały $\mathrm{z}$ reguły już $\mathrm{w}$ asystencji męża lub krewnych, co literatura przedmiotu jednoznacznie thumaczy jako tendencje $w$ kierunku odebrania mężatce zdolności procesowej ${ }^{8}$. Sporo wiadomości o związkach rodzinnych przynoszą zapisy wiana lub zrzeczenia się praw do nich przez kobiety.

3. W naszych rozważaniach zajmiemy się tylko wieloznacznymi terminami pokrewieństwa i powinowactwa.

W łacinie klasycznej avus, avia oznaczały dziadka i babkę. W tym znaczeniu posługiwano się tymi wyrazami nagminnie, nie rozróżniając jednak linii ojczystej i macierzystej. W 1473 r. Elżbieta, córka Jana z Dzierlina i Anny z Otoka, nazywa Stanisława z Otoka avum germanum. Był to jej dziad macierzysty. Ten stopień pokrewieństwa potwierdza nazwanie przez ową Elżbietę Mikołaja z Otoka, syna Stanisława, avunculum suum germanum. Rodzona siostra Elżbiety, Katarzyna, wspomina w 1476 r. Katarzynę, jako swoją avam germanam ${ }^{9}$, nie dodając, że chodzi o babkę macierzystą.

Tego samego terminu $\mathrm{z}$ przymiotnikiem germanus (rodzony) używano dla określenia rodzeństwa dziadków. W 1449 r. Jan z Borzewiska wystąpil o 100 grzywien posagu po zmarłej Barbarze, żonie Piotra Korablewskiego z Bałucza, post avam germanam. Tymczasem byla to siostra jego dziada ojczystego Mikołaja. Błędnie też określił Jan Borzewiski więź łączącą pozwanego przezeń Jana Otockiego z Piotrem Korablewskim, nazywając tego ostatniego stryjem Jana. Piotr Korablewski, będąc rodzonym bratem Stanisława, dziada ojczystego Jana Otockiego, był w rzeczywistości dziadem stryjecznym ${ }^{10}$.

Tę samą odległość genealogiczną wskazuje zapiska z 1485 r., tylko na pozór nielogiczna. Tomasz ze Skarżyna, syn Mikołaja, skarżył Wincentego $\mathrm{z}$ Ciemina, że ten zajął jego patrualia alias dziadowizna w Skarżynie post honorabilem Andream avum ipsius ${ }^{11}$. Tymczasem chodzi tu o spadek po zmarłym w 1485 r. bracie dziada ojczystego - Andrzeju, plebanie z Ostrzeszowa.

Śladem uźywania w Sieradzkiem zwrotu stara mać, „stara matka" w znaczeniu babki, jest zapiska z 1443 r., w której wspomniany został Jan

7 AGAD, KZS, ks. 10, k. 26; AGAD, KZSz., ks. 4, s. 78; AGAD, KGS, ks. 1, k. 14; ks. 5 , s. 143,305 ; ks. 8 , s. 859 ; ks. 11 , s. 93.

${ }^{8}$ M. Koczerska, Rodzina szlachecka w Polsce późnego średniowiecza, Warszawa 1975 , s. 67.

9 AGAD, KGS, ks. 18 , s. 90; ks. 19, s. 291; ks. 20, s. 28.

10 AGAD, KZSz., ks. 7, s. 131.

11 AGAD, KZS, ks. 13, k. 131v. 
Świniecki cum ipso matre alias ava Margareta ${ }^{12}$. Istotnie, Małgorzata z Umienia była żoną Chebdy ze Świnic i babką Jana.

Ustalenie konkretnego znaczenia terminu avus propinquus jest możliwe tylko wówczas, gdy szczęśliwym zbiegiem okoliczności o danej osobie zachowają się liczniejsze wzmianki. Tak właśnie w 1482 r. nazwała Małgorzata (córka Jakuba Cieńskiego z Lubnej i Anny z Kliczkowa) Michała z Sędzic. Ale w 1471 r. wspomniana Anna określiła Michała avunculo germano ${ }^{13}$. Dla Malgorzaty byl on zatem bratem rodzonym babki macierzystej. Na oznaczenie tego stopnia pokrewieństwa Bartłomiej z Bydgoszczy $\mathrm{w}$ swoim słowniku wprowadzil nazwę wielki wuj, jednak także nie precyzując, czy chodzi o brata babki ojczystej czy macierzystej ${ }^{14}$.

Do terminów niejednoznacznych należy również patruus sensu stricto, stryj, czyli brat ojca. W 1474 r. Mikolaj i Stanislaw z Lipek - synowie Jana Grzymały h. Grzymała - dali Zofii, sorori suae germanae, a żonie Bronisza z Woli Grabiny 130 grzywien posagu. Zofii asystowali: Klemens z Biskupic patruus i Jan Grądel z Zakrzowa avunculus ${ }^{15}$. Klemens z Biskupic należał do rodu Lisów. Dlaczego więc zostal nazwany stryjem? Otóż z tej przyczyny, że w występującym wówczas gronie osób reprezentowal stronę po mieczu. Babką ojczystą Zofii byla Katarzyna z Bechcic h. Lis, rodzona siostra Stefana z Biskupic, ojca Klemensa. Średniowieczni pisarze używali więc terminu patruus nie tylko w znaczeniu brat ojca, ale także na określenie innych krewnych ojca, należacych do jego pokolenia lub członków tego samego rodu ${ }^{16}$.

Następna sprawa dostarcza kolejnego przykładu na swobodne traktowanie przez pisarzy średniowiecznych ksiąg sądowych kwestii genealogicznych. W 1493 r. Anna $\mathrm{z}$ Wilamowa, wdowa, zawarła ugodę $\mathrm{z}$ dziećmi swego męża - Mikołaja Grzymały z Lipek, zrodzonymi z jego pierwszego małżeństwa z Katarzyną z Rzeczycy. Jednaczami byli patrui ipsorum puerorum, wymienieni w następującej kolejności: Mikołaj z Miłkowic, Stanisław z Lipek, Jan $\mathrm{z}$ Borzewiska, Stefan $\mathrm{z}$ Rudnik i Mikolaj z Businy ${ }^{17}$. Z tego grona stryjem rodzonym był jedynie Stanisław. Do krewnych ze strony ojca należał też Mikolaj z Businy, spokrewniony z dziećmi w VII. stopniu w linii bocznej (dziad Mikołaja i pradziad dzieci byli rodzonymi braćmi), który mieścił się jeszcze w ogólnym pojęciu stryjów. Trudno natomiast do stryjów zaliczyć Mikołaja z Milkowic h. Pomian, skoro jako brat rodzony Doroty, babki

${ }^{12}$ AGAD, KGS, ks. 8, s. 155; M. Szymczak, op. cit., s. 62.

${ }^{13}$ AGAD, KGS, ks. 17 , s. 79 ; ks. 22, s. 472 .

14 Slownik lacińsko-polski Barlomieja z Bydgoszczy podlug rekopisu z roku 1532, wyd.

B. Erzepka, Poznań 1900, s. 129.

15 AGAD, KGS, ks. 18, s. 198.

16 AGAD, KZSz., ks. 5, s. 348.

17 AGAD, KGS, ks. 27, s. 680 . 
ojczystej potomków Mikołaja Grzymały, należał do pokolenia dziadów! Stefan z Rudnik $h$. Lis był bratem ciotecznym dla sierot, synem Doroty z Ralewic i Rzeczycy, rodzonej siostry ich matki - Katarzyny. Może zaliczenie go do kategorii krewnych o pokolenie starszych wynikało $\mathrm{z}$ faktu, iż różnica wieku między rodzeństwem ciotecznym przekraczała 20 lat. Najtrudniej wyjaśnić użycie terminu patruus w odniesieniu do Jana z Borzewis$\mathrm{ka}$ h. Pomian, którego $\mathrm{z}$ dziećmi nie łączyło ani pokrewieństwo ani powinowactwo. Jan był bowiem wnukiem Beaty z Wroczyn, która po śmierci jego dziada ojczystego - Mikołaja, wyszła powtórnie za mąż za Jana Grzymałę z Lipek - dziada dzieci, ale babką ich nie była! Wybór wiẹc przez pisarza terminu patrui jako wspólnej zbiorowej nazwy dla wymienionych wyżej osób stanowiło jawne, choć formalne nadużycie $\mathrm{z}$ jego strony. W tej sprawie uderza także brak osoby, która by reprezentowała interesy majątkowe macochy w sporze $\mathrm{z}$ pasierbami.

Termin avunculus germanus, avunculus germanus post matrem oznaczał wuja, czyli brata matki ${ }^{18}$. Oprócz tego zasadniczego znaczenia był on uźywany - podobnie jak dziś - dla określenia licznych krewnych ze strony matki. Dobrze ilustruje to zapiska z 1487 r. Anna - żona szlachcica Jana, łaziebnika z Lęczycy - kwitowała Mikołaja z Szadowa, ze splaty przypadającej jej części dziedzictwa po Wacławie z Szadowa - avunculo germano, w obecności Strzeszka z Kaczek - avunculo propinquo, i Mikołaja Luboskiego - avunculo ${ }^{19}$. Mamy zatem trzech wujów, $\mathrm{z}$ których każdy pozostawał z Anną w innym stopniu pokrewieństwa, choć trudnym do określenia na podstawie zachowanych materiałów. W 1473 r. Marcin $z$ Wójcic h. Pomian oprawil swej żonie - Annie, 60 grzywien na swych dobrach. Zapis ten aprobowal krewny ze strony Anny, a mianowicie Jan Rowieński z Wójcic, odnotowany jako jej avunculus patruelis germanus ${ }^{20}$. Ten łaciński zwrot jest zapewne tłumaczeniem określenia: wuj stryjeczny rodzony, czyli brat stryjeczny matki. Sprawdźmy tę wykładnię, śledząc genealogię Anny Wójcickiej i Jana Rowieńskiego. Anna była córką Piotra ze Smaszkowa i Kostrzewic oraz Małgorzaty Pratkowskiej - córki Piotra z Równej h. Paparona i Katarzyny z Pratkowa. Poshugiwanie się przez Piotra z Równej protonazwiskiem Pratkowski było konsekwencją przeniesienia się $w$ dobra żony ${ }^{21}$. Bratem rodzonym Piotra byl Grzegorz Gąska z Równej, który miał syna Jana, nabywcę Wójcic. Łączył więc Annę z Janem Rowieńskim V. stopień pokrewieństwa w linii bocznej, prawidłowo wyrażony w cytowanym zapisie.

W 1486 r. Mikołaj - wójt Warty, syn Dobrogosta z Woli Berwoldowej - powołał na świadka zastawu Jana Żelisławskiego ze Słomkowa Mokrego,

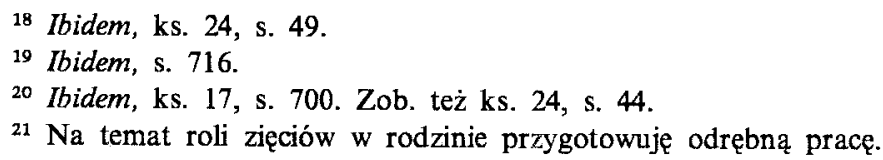


avunculum suum amitalem germanum ${ }^{22}$. I tu również mamy do czynienia z V. stopniem pokrewieństwa w linii bocznej. Babka macierzysta Mikolaja - Dorota ze Zborowskich, żona Marcina $z$ Warty - była rodzoną siostrą Elżbiety ze Zborowskich, matki Jana Żelisławskiego.

Omawiany zwrot avunculus germanus nie jest więc precyzyjny. Równie dwuznaczny jest termin amita, nie rozróżniający siostry ojca od siostry matki, a w konsekwencji także rodzeństwa żeńskiego dziadka i babki ojczystych od macierzystych.

Dystans zachować należy nawet do tak zdawałoby się oczywistych relacji genealogicznych jak frater germanus, czyli brat rodzony. I tu bowiem zdarzają się pomyłki. W 1466 r. Katarzyna - żona Jana Radlicy z Pęczniewa h. Korab - pożyczyła posagowe 110 grzywien Andrzejowi z Łasku, pod zastaw wsi Orchów. Świadkiem Katarzyny był Jan z Rudnik - frater germanus. Rudniki leżały w parafii Pęczniew i w tym czasie należały do Lisów, do którego rodu $\mathrm{z}$ racji na wskazane pokrewieństwo winna też należeć Katarzyna. Tymczasem w 1483 r., już jako wdowa, zapisała ona 10 grzywien $z$ wyżej wymienionej sumy dominikanom w Lęczycy w obecności Jana ze Śladkowa $z$ Lęczyckiego - fratrem suum propinquum. Ten sentyment do dominikanów lęczyckich (chociaż zakonnicy byli bliżej w Sieradzu), jak też prośba, aby właśnie w ich klasztorze ją pochować, wskazują, że pochodziła z ziemi lęczyckiej. Nie żyła już w 1489 r., a zatem przytoczony wpis ma charakter testamentu. Katarzyna zmarła bezdzietnie, więc do spadku po niej, tj. owych 110 grzywien na Orchowie, zgłosili się liczni krewni z ziemi lęczyckiej i dobrzyńskiej. Łęczyccy krewni pochodzili z Krzyżanówka, gdzie siedzieli Sulimowie. Nazwali oni Katarzynę amitam germanam i jako miejsce jej pochodzenia wskazali Krzyżanówek. Dla dopełnienia zawartej ugody zainteresowani winni stawić jeszcze jednego Sulimczyka, a mianowicie ich fratrem propinquum post patrem Jakuba z Oporówka ${ }^{23}$. Tak więc Jan z Rudnik nie mógł być w żaden sposób jej bratem rodzonym, lecz co najwyżej ciotecznym ze strony matki.

Dalsze stopnie pokrewieństwa $w$ linii bocznej osób należących do kategorii braci podawane są w sposób opisowy. W 1484 r. Felicja - córka nie żyjącego już Jana Ziemięty $z$ Piotrowa i Jeżewa - sprzedając swoje dziedzictwo w Jeżewie, nazwała nabywcę, Jakuba Wroniawskiego z Lichawy fratre patrueli de patruelibus germano ${ }^{24}$. Łączył ich VI. stopień pokrewieństwa. Drugą osobą, która jej asystowala w sądzie, byl Jakub z Krokocic - frater avuncularis, brat wujeczny, czyli syn brata matki.

Podobnie Anna Laska - żona Rafala z Chorzepina, siostra Jaroslawa, wojskiego mniejszego sieradzkiego - w 1496 r. zrzekła się oprawy zapisanej

${ }^{22}$ AGAD, KGS, ks. 24, s. 595. Zob. też AGAD, KZSz, ks. 4, s. 752-753; AGAD, KGS, ks. 28 , s. 428 .

${ }^{23} \mathrm{AGAD}, \mathrm{KGS}$, ks. 14, s. 440 ; ks. 23, s. 206; ks. 26, s. $79,103$.

24 Ibidem, ks. 23, s. 483. 
na sprzedanym przez męża Chorzepinie wobec: Marcina Aarona z Wójcic - fratre ex patruelibus germano post patrem, Adama $\mathrm{z}$ Rembieszowa - fratre amitali, i Mikołaja Krokockiego - fratre propinquo ${ }^{25}$. Najlatwiej rozszyfrować wśród nich Adama $\mathrm{z}$ Rembieszowa - syna Katarzyny $\mathrm{z}$ Rembieszowa i Marcina z Koziebrodów. Katarzyna byla rodzoną siostrą Barbary, matki Anny Laskiej. Trudniej ustalić pokrewieństwo Anny z pozostałymi osobami. Marcin Aaron pochodzil z Mroczek i Dąbrowy w Kaliskiem. Wójcice stanowily oprawę jego żony Anny, wdowy po Marcinie Budku. Należal do rodu Korabitów i nosił imię powtarzające się wśród potomków Wojciecha - kasztelana lędzkiego, pradziada po mieczu Anny Laskiej. Nie wykluczone więc, że mieli wspólnego pradziada. Niejasno rysuje się pokrewieństwo trzeciego świadka. Mikołaj Krokocki był $\mathrm{w}$ tym czasie sędzią grodzkim sieradzkim i z tytułu swej funkcji uczestniczyl w akcji prawnej. We wszystkich sprawach tego rodzaju występowali na ogół dwaj świadkowie, reprezentujący rodzinę kobiety po mieczu i po kądzieli. Trudno wszakże jednoznacznie stwierdzić, czy termin frater propinquus w przypadku Krokockiego oznaczal brata klejnotnego - należal bowiem także do rodu Korabitów - czy też lączyły go z Laskimi bliższe związki ${ }^{26}$.

Wspomniana już dwuznaczność terminu amita występuje oczywiście również $w$ pojęciu frater amitalis. Nie powiodło się zaszczepienie do praktyki sądowej klasycznego terminu matertera dla wyróżniania siostry matki. Pisarze za rzadko korzystali z możliwości leksykalnych ulatwiających rozróżnienie więzi genealogicznych. Przykładem takiego dobrego wykorzystania zasobów języka łacińskiego jest zapiska z 1464 r.: Katarzyna, córka Stanisława z Wójcic i Małgorzaty z Górek, sprzedala Wójcice Janowi z Równej. Świadkami tej transakcji było 5 csób: Mikołaj z Górek, avunculus, Małgorzata matka, ponownie zamężna za Janem z Chrzanowic, Agnieszka, żona Bartosza $\mathrm{z}$ Koldowa, amita germana, Tomasz $\mathrm{z}$ Janowic i Błaszek, frater amitalis post patrem Katerinae oraz Dzierslaw z Borysławic, patruus dicte Katerinae ex patrueli germanus ${ }^{27}$. Występujące $w$ zapisie więzi pokrewieństwa są czytelne. Interesujący nas tutaj Tomasz, spokrewniony z Katarzyną w IV. stopniu, był synem Małgorzaty z Wójcic - siostry rodzonej Stanisława, ojca Katarzyny. Dziersław z Borysławic byl dla Katarzyny stryjem stryjecznym (V. stopień pokrewieństwa) ${ }^{28}$.

${ }^{25}$ Ibidem, ks. 28, s. 574; S. Kozierowski, Ród Korabitów. Studia nad pierwotnym rozsiedleniem rycerstwa polskiego, t. 12, Lomża 1933, s. 46.

${ }^{26}$ Podobny przypadek asystencji herbowych stryja i wuja podaje Slownik historyczno-geograficzny wojewỏdztwa krakowskiego w średniowieczu, cz. II, z. 4, red. F. Sikora, Kraków 1993 , s. 656.

${ }^{27}$ AGAD, KGS, ks. 13, s. 900-901.

${ }^{28} \mathrm{Na}$ określenie brata ciotecznego w księgach sieradzkich używano jeszcze nazwy frater amitabilis, ibidem, ks. 18, s. 222. 
W opisach pokrewieństwa zdarzają się pisarzom przeskoki pokoleniowe. W 1498 r. Anna z Charłupi Małej i Losieńca - żona Michała ze Zborowskich, córka Piotra i Katarzyny - powołała jako świadków Sędziwoja i Jana z Grąd, synów Jana, kasztelana spicymierskiego, fratres suos patrueles germanos ${ }^{29}$. Tymczasem braćmi stryjecznymi byli ich ojcowie, toteż Annę z Grądzkimi łączył nie IV., ale VI. stopień pokrewieństwa.

Najwięcej problemów interpretacyjnych przysparzają nam przymiotniki propinquus, propinquior - umieszczone obok terminu oznaczającego pokrewieństwo lub powinowactwo. Propinqui w formie rzeczownikowej używano jako jednego $\mathrm{z}$ określeń zbiorowych na krewnych $\mathrm{w}$ ogóle. Pod terminem frater propinquus może ukrywać się każdy krewny z tego samego pokolenia. Oto kilka przykładów. W 1483 r. Anna - żona Marka Szelerzewskiego ze Śląska - wyprocesowała 100 grzywien posagu, należnych jej po matce Dorocie, które ta miała zapisane na królewszczyźnie w Krasicach. Dzierżawcą tych dóbr w tym czasie był Andrzej Pielsza z Brodły w Krakowskiem. Przed sądem Annie asystowali Jan Krokocki - pleban w Strońsku, i Jan z Podłężyc - fratres propinqui.

W 1499 r. Anna już nie żyła, podobnie jak jej jedyna siostra Katarzyna. Obie zmarły bezpotomnie, toteż o zwrot posagów wystąpil Mikołaj Krokocki - brat rodzony Jana, plebana w Strońsku - pozywając kolejnego tenutariusza w Krasicach, Jakuba Pielsza z Brodky, o 50 grzywien post nobilem Annam [pomylka w zapisie; winno być Dorota] olim amitam ipsius germanam necnon post nobiles Katerinam et Annam sorores germanas amitales ${ }^{30} . \mathrm{Z}$ obu wzmianek wynika, że tym razem frater propinquus oznacza brata ciotecznego. Mikołaj wystąpił dokładnie o połowę sumy posagowej, do drugiej części mogły zatem rościć pretensje jego siostrzeńcy - dzieci Anny Balińskiej, bowiem pleban Jan już nie żył. Jeśli chodzi o osobę Jana z Podłężyc, to możemy się tylko domyślać, że należał do krewnych ze strony ojca Anny Szelerzewskiej.

Podobne rozwiązanie stwierdza zapiska z 1452 r.: Jadwiga, żona Jana z Zalewu, (córka Mikołaja z Pągowa i Anny z Paprotni) po śmierci ojca sprzedała za 30 grzywien swoje części w Paggowie Stanisławowi i Janowi, swym stryjecznym braciom. Asystowali jej przy tym fratres propinqui, a byli to: Jan z Pągowa, frater patruelis germanus i Franek, frater amitalis ${ }^{31}$. W rodzinie Pągowskich h. Kamiona występuje Jan - syn Pawła, rodzony

${ }^{29}$ Ibidem, ks. 29, s. 28. W 1490 r. Barbara Grabska kwitowała brata ze spłaty. Towarzyszyli jej: Mikołaj z Małkowa i Stanisław Grzymała z Lipek fratres propinqui (ibidem, ks. 26, s. 367). Należeli oni jednak do dwóch pokoleń. Mikołaj byl wnukiem rodzonym Stanisława. Mikołaj miał matke h. Pomian, tego samego herbu była Barbara Grabska.

30 AGAD, KGS, ks. 27 , s. $986-987$; ks. 29, s. 425 . Zob. też ks. 25 , s. 135 , gdzie frater propinquus $=$ brat cioteczny rodzony.

31 AGAD, KGS, ks. 10, s. 702. 
brat Mikołaja, ojca Jadwigi. Nie wiadomo natomiast, kim był Franek. Ze względu na charakter alienacji, obejmującej paternalia et maternalia, należy sytuować go wśród krewnych po kądzieli. Już chyba tylko z nadgorliwości stron lub pisarza znalazło się takie określenie Czesława $\mathrm{z}$ Tądowa: frater ex patruelibus germanus propinquus dla Jadwigi $\mathrm{z}$ Tądowa ${ }^{32}$.

W świetle powyższych uwag mało przekonywające jest wnioskowanie o przynależności rodowej na podstawie tak ogólnie określanego pokrewieństwa. W $1495 \mathrm{r}$. córki Świętosława z Milejowa h. Kamiona i Katarzyny z Poddębic h. Pomian; Dorota - żona Macieja Straszkowskiego, i Małgorzata - żona Jana z Ziemięcina sprzedały dobra w obecności Świętosława z Ostrowa h. Korab, patruum [!] propinquum, i Jana Rowieńskiego h. Paparona, avunculum [!] propinquum ${ }^{33}$.

W literaturze przedmiotu zwrócono już uwage na wymienne stosowanie nazw: germanus i uterinus ${ }^{34}$. Zjawisko to jest obecne także w źródłach sieradzkich. W 1422 r. Dziersław z Grąd oddal się w opiekę swym synom: Przedwojowi i Mikołajowi, od trzeciego zaś syna - Chwała, ich fratri uterino - uzyskal zrzeczenie się praw do siedliska, przekazanego opiekunom. W następnych przekazach wszystkich synów Dziersława, występujących w różnych parach, zawsze określano germani ${ }^{35}$. Warto też odnotować, że Mikołaj i Przecław - synowie Jaranda $\mathrm{z}$ Grabna - nazywani są fratres germani, choć mieli różne matki ${ }^{36}$.

Termin uterini oznaczać winien dzieci zrodzone $\mathrm{z}$ jednej matki, ale $\mathrm{z}$ różnych ojców. Tymczasem w źródłach sieradzkich często objaśnia sytuacje odmienną - mianowicie dzieci zrodzone $\mathrm{z}$ jednego ojca, ale $\mathrm{z}$ różnych matek. W 1486 r. Jan ze Zduńskiej Woli zastawil część wsi ojcowskiej za zgodą Doroty, sororis ipsius uterinae, unius patris et alterius matris ${ }^{37}$. Jan był synem Jachny z Krokocic, Dorota zaś - Małgorzaty Kuneckiej ze Strachocic.

W 1454 r. synowie Jarosława $z$ Ostrowa (par. Brzeźnio) wydzielili najstarszego $\mathrm{z}$ braci - Jana $\mathrm{w}$ związku $\mathrm{z}$ jego ożenkiem. Otrzymal on czwartą część ojcowizny w Ostrowie oraz trzecią część macierzyzny w Słomkowie Mokrym. Macierzyzna została podzielona tylko pomiędzy 3 braci, ponieważ quartus frater est przyrodek, czyli $z$ innej matki! ${ }^{38}$

32 Ibidem, ks. 28, s. 213.

33 Ibidem, s. 104-105.

${ }^{34}$ M. Koczerska, Uwagi..., s. 33 .

${ }^{35}$ AGAD, KGS, ks. 4, s. 511; KZS, ks. 8, k. 14v; ks. 9, k. 220; KZSz., ks. 2, s. 187, 230; Acta capitulorum nec non iudiciorum ecclesiasticorum selecta, wyd. B. Ulanowski, t. 1, Kraków 1894, nr 1623. Zob. AGAD, KGS, ks. 3, s. 297: Mikołaj z Chorzeszowa, wójt lutomierski, poręczał za Paska, fratre suo germano; KZSz., ks. 1, k. 123: Mikołaj i Pasek $\mathrm{z}$ Chorzeszowa fratres uterini.

${ }^{36}$ AGAD, KZSz., ks. 3, s. 566.

${ }^{37}$ AGAD, KGS, ks. 24, s. 563.

${ }^{38}$ Ibidem, ks. 11, s. 174. Zob. też AGAD, KZS, ks. 13, k. 72; AGAD, KGS, ks. 15, s. 206. 
W tym samym znaczeniu występuje uterinus w kolejnej sprawie. W $1462 \mathrm{r}$. bracia stryjeczni z Tokar dokonali działu dóbr po zmarłych stryjach. Spadkobiercami czéści w Tokarach byli synowie Piotra: Jan, Stanisław, Jakub oraz drugi Jan - adnativus alias przirodni. Tenże Jan został nieco dalej $w$ tej samej zapisce określony jako frater ipsorum uterinus alias przirodni ${ }^{39}$.

Potomstwo Piotra Zajączka - kasztelana rozpierskiego, z jego dwóch małżeństw ( $\mathrm{z}$ Warszką i Heleną) nazywane jest także jako uterini ${ }^{40}$. W $1478 \mathrm{r}$. Jan $\mathrm{z}$ Bęczkowic naganil Andrzeja, fratrem suum unius patris sed alterius matris alias bracia przyrodniq ${ }^{41}$, który udowodnił swoje szlachectwo $\mathrm{z}$ herbu Pomian ze strony matki. Uterinus może być też avunculus ${ }^{42}$.

Terminy filiaster i filiastra oznaczały najczęściej synowca i synowicę, czyli dla brata syna lub córkę brata. Poprzez połączenie z przymiotnikami: patruelis, propinquus, tworzono dalsze stopnie pokrewieństwa w linii bocznej. W 1477 r. Jan z Lutomierska - sędzia sieradzki - nazwal Małgorzatę Witowska, córkę swego brata stryjecznego, Szymona z Czołczyna, filiastra sua patrueli germana ${ }^{43}$ (V. stopień pokrewieństwa).

Rozmaite nazwy lacińskie stosowano dla określenia relacji siostra - potomstwo brata. Spotyka się formę opisową: filius fratris germani alias Bratanek. W 1417 r. Hanka - wdowa po Chebdzie z Gzikowa - zapisala 150 grzywien na Wójcicach Janowi, Piotrowi i Mikołajowi z Topoli k. Lęczycy: fraterinis suis germanis alias Bratankam. W 1421 r. Dzierżka z Kobierzycka nazywa Jarosława $\mathrm{z}$ Rembieskich confraterinus germanus ${ }^{44}$.

Zróżnicowanie terminologii pokrewieństwa, w zależności od osoby nazywającej, oddal prawidłowo pisarz w zapisce z 1485 r. Katarzyna - córka Piotra $\mathrm{z}$ Kosowa i Doroty $\mathrm{z}$ Biernacic, żona Jana $\mathrm{z}$ Borzewiska - została wówczas nazwana filiastra, czyli synowica, w stosunku do swego stryja Mikołaja - kantora kruszwickiego i kanonika uniejowskiego. Byla natomiast neptis, czyli bratanica, dla swojej ciotki Katarzyny Przatowskiej, rodzonej siostry Mikolaja i Piotra Kosowskich ${ }^{45}$.

Terminy: filiaster i filiastra, były - co dla historyka bardzo niebezpieczne - często traktowane jako synonimy nazw: sororinus i sororina, oznaczających siostrzeńca i siostrzenice. W $1480 \mathrm{r}$. Wacław z Kraszyna wypłacił 6 grzywien posagu Wojciechowi z Nowych Kozub za sororinam Katarzynę. W $1482 \mathrm{r}$. dodal mu jeszcze 5,5 grzywny za Katarzynę, filiastram suam germanam $^{46}$.

39 AGAD, KGS, ks. 13, s. 195.

40 Ibidem, ks. 25, s. 33 .

41 Ibidem, ks. 20, s. 52 . O dzieciach nieślubnych i ślubnych nieprawych zob. J. M a t u s z e w ski, Proles illegitima w polskim prawie ziemskim, CPH 1968, t. 18, z. 2, s. 71-154.

42 AGAD, KZS, ks. 6, k. 16v.

43 AGAD, KZSz., ks. 6, s. 84-85.

44 AGAD, KGS, ks. 3, s. 442; ks. 11, ks. 688; AGAD, KZS, ks. 7, k. $195 v$.

45 AGAD, KZSz., ks. 6, s. 340.

46 AGAD, KGS, ks. 21, s. 135; ks. 22, s. 637 ; ks. 17, s. 687 . 
Droga analogii do form klasycznych powstawały w żywej lacinie średniowiecznej nowe twory jezzykowe. W 1419 r. Bogusz ze Zborowskich - opiekun swych siostrzeńców - miał doprowadzić Jana, sororiastrum suum, celem rezygnacji $\mathrm{z}$ solectwa $\mathrm{w}$ Sulmierzycach ${ }^{47}$. W ten sposób utworzono pary wyrazów: sororinus - fraterinus, filiaster - sororiaster, dla rozróżnienia potomstwa brata i siostry.

Dalsze stopnie pokrewieństwa, łączące tę kategorię krewnych, były podawane w sposób opisowy. W 1489 r. Marcin z Glaniszewa powołując się na prawo bliższości wystąpil o 2 lany w Głaniszewie, sprzedane przez Stanisława z Bujnowa sororinum ipsius Martini patruelibus germanum, czyli syna siostry stryjecznej. Zostal jednak oddalony $w$ prawie, albowiem nie obejmowal go porządek dziedziczenia $\mathrm{z}$ racji na $\mathrm{V}$. stopień pokrewieństwa ${ }^{48}$.

Powróćmy do terminu nepos, neptis. Bartłomiej z Bydgoszczy w słowniku lacińsko-polskim z 1532 r. jako pierwsze znaczenie tych wyrazów podaje: wnuk, wnuczka - bez rozróżnienia czy chodzi o potomstwo po synu czy po córce ${ }^{49}$. Pisarze ksiąg sieradzkich używając tych słów w takim właśnie - wziętym z laciny klasycznej - znaczeniu, pisali: nepoti suo vulgariter wnukowi $^{50}$. W 1454 r. Pielgrzym z Janowic przekazal swoje dobra w Janowicach Tomaszowi i Andrzejowi - synom swej córki Małgorzaty z Błaszek i Wojciecha Kątnego, suis privignis alias wnukam. Termin privignus oznaczal pasierba, użyty więc został $w$ tych okolicznościach wyjątkowo niefortunnie. Potwierdza to kolejna zapiska. W $1456 \mathrm{r}$. wspomniany Pielgrzym, po śmierci Andrzeja, zapisal 100 grzywien drugiemu z braci - Tomaszowi, nepoti suo vulgariter wnuk $^{51}$.

Średniowieczna Europa poszerzyla zakres semantyczny tych słów na potomstwo rodzeństwa. To drugie tłumaczenie podaje także Bartłomiej z Bydgoszczy ${ }^{52}$. Wybór właściwego znaczenia w tekście może więc nastręczać trudności. Przed 1485 r. Jan Wężyk z Woli - podkomorzy sieradzki - kupił części w Zapolicach od Heleny, żony Dziersława z Ułan. W $1488 \mathrm{r}$. kwitowała ona nabywcę ze spłaty w obecności Wojciecha Kamionomojskiego z Pstrokoni, fratrem amitalem germanum i Jakuba z Zapolic, nepotem suum. W 1489 r. Jakub zastawił Helenie, amite germane, 3,5 łana w Strońsku za 35 grzywien. Helena była ciotka Jakuba ze strony ojca - zatem terminem nepos wskazano tu bratanka ${ }^{53}$. Tymczasem w 1495 r. Jakub Zapolski ze Strońska nazwany został bratem Heleny! Ten błąd weryfikuje zapiska

${ }^{47}$ AGAD, KZS, ks. 6, k. 63v.

48 Ibidem, ks. 13, k. $217 \mathrm{v}$.

49 Slownik lacińsko-polski..., s. 130.

50 AGAD, KGS, ks. 11, s. 697; por. M. Koczerska, Uwagi.., s. 38.

51 AGAD, KGS, ks. 11, s. 208, 697.

52 Slownik lacinsko-polski..., s. 130.

53 AGAD, KGS, ks. 25, s. 137; ks. 26, s. 99-100; KZSz., ks. 6, s. 740. 
z 1497 r., w której Helena, mając u boku Jakuba ze Strońska, nepotem ipsius propinquum alias Brathanka, odebrała ostatniq ratę za sprzedane dziedzictwo od Anny Wężykówny - córki podkomorzego ${ }^{54}$. Warto tu zwrócić uwage na przymiotnik propinquus, będący w tym przypadku synonimem terminu germanus.

W 1460 r. Przybysław z Łobudzic i Woli Lobudzkiej sprzedał Lobudzice Janowi, Jakubowi, Stanisławowi i Rafalowi z Chorzepina, nepotibus suis seu filiastris, $\mathrm{t} \mathrm{j}$. synowcom ${ }^{55}$.

Liczne przykłady potwierdzaja thumaczenie nepos i neptis jako siostrzeniec i siostrzenica. W 1423 r. Grzegorz Gąska z Równej uzyskał opiekę nad dziećmi Piotra ze Świerczowa i jego zmarłej żony suis nepotibus alias syestrzenyanthami ${ }^{56}$. W 1427 r. Jarand z Rososzycy jako avunculus tutor nepotum seu sororinorum suorum otrzymał opiekę nad dziećmi swej zmarłej siostry Doroty, żony Adama z Korczewa ${ }^{57}$.

Do tego zasobu określeń dorzućmy jeszcze jedno znaczenie. W $1487 \mathrm{r}$. Jadwiga z Magnus Starych - żona Wojciecha z Chodaków - w asystencji Jana, brata stryjecznego rodzonego z Magnus, kwitowała Jakuba z Magnus, rivalum suum, ze spłaty 12 grzywien dziedzictwa. W tejże zapisce czytamy, że Jakub wyplacił Wojciechowi Chodakowskiemu 8 grzywien posagowych za Jadwigę, neptem alias po svyeszczyschevye ${ }^{58}$. W dawnej polszczyźnie termin świeść oznaczal siostrę żony. Dla ustalenia wiążącej te osoby koligacji kluczowe znaczenie posiada określenie rivalis. Bartłomiej z Bydgoszczy identyfikuje go $\mathrm{z}$ polskim swakiem i objaśnia jako męża siostry ojca ${ }^{59}$. W okresie wcześniejszym znaczenie słowa swak było szersze. Występował on przede wszystkim dla określenia męża siostry, następnie męża siostry ojca lub siostry matki ${ }^{60}$. To ostatnie znaczenie współgra $\mathrm{z}$ treścią pojęcia świeść. Neptis więc $\mathrm{w}$ tym wypadku oznaczał córkę siostry żony.

M. Szymczak wyróżnia - jak pamiętamy - 17 nazw własnych z zakresu powinowactwa rodzinnego do III. stopnia w linii bocznej. Odrębna terminologia obejmowała rodziców męża i żony, rodzeństwo każdego z małżonków,

54 AGAD, KGS, ks. 28, s. 174; KZSz., ks. 7, s. 50 .

ss AGAD, KGS, ks. 12, s. 644.

${ }^{36}$ AGAD, KZS, ks. 7, k. 252v.

37 AGAD, KZSz., ks. 3, s. 232.

58 Ibidem, ks. 6, s. 433. Zob. też AGAD, KZS, ks. 12, k. 185v. W 1416 r. przed sądem w Czersku stanął Mikołaj Kot ze Służewa $w$ zastępstwie swej żony i Tochny, amite sue vulgariter swesczi (!) - Ksiega ziemi czerskiej 1404-1425, wyd. T. Lubomirski, Warszawa 1879, $\mathrm{nr} 438$.

50 Slownik lacinsko-polski..., s. 131.

60 M. Sz y m czak, op. cit., s. 173. Wzmianka ta stanowi dowód, którego nie znalazł M. Szy mczak (op. cit., s. 185) na używanie już w XV w. nazwy swak również w znaczeniu mąż ciotki. 
a także żony stryja i wuja oraz męża ciotki ${ }^{61}$. I tutaj mamy do czynienia $\mathrm{z}$ wieloznacznością terminów łacińskich lub wielonazwowością jednego desygnatu.

W 1429 r. Nastka - wdowa po Pełce z Rembieskich - nazywa Jana suo uxorino vel dzewierz. W języku staropolskim dziewierz oznaczał brata męża. $\mathrm{Z}$ takim znaczeniem terminu uxorinus moglibyśmy się zgodzić, bowiem w innym miejscu Jan określa Nastkę glote sua (jedno ze znaczeń to bratowa), zaś jej córkę Annę - filiastra ${ }^{62}$. Gdyby nie polski wyraz dziewierz, w nazwie uxorinus upatrywalibyśmy raczej brata żony.

Drugą nazwą łacińską (podawaną też przez słowniki) dla określenia tego związku powinowactwa był levir. W 1488 r. Agnieszka - wdowa po Andrzeju z Kaczek Płastowych - wspólnie z Janem z Kaczek, leviro suo alias dziewierz, procesowala się z Feliksem z Szadowa Pańskiego ${ }^{63}$. Trzecim terminem łacińskim, którego użyto w znaczeniu dziewierza, byl consobrinus ${ }^{64}$.

Wiele znaczeń nadawano lacińskiemu terminowi glos. Bartłomiej z Bydgoszczy nazwał $w$ ten sposób żonę brata, ale też i siostrę męża ${ }^{65}$.

Terminologia polska dotycząca różnych typów relacji, w jakie wchodziło rodzeństwo wspólmałżonków, jest bardzo bogata. Brat żony nazywał się szurza, siostra żony - świeść, zaś siostra męża - zelwa. Osobne nazwy obejmowały małżonków rodzeństwa. Żona brata nazywała się jątrew (gdy nazywającą była siostra) lub bratowa (gdy nazywającym był brat), zaś mąż siostry to swak.

Wszystkie kobiety występujące w wymienionych wyżej relacjach określane były jednym terminem lacińskim glos. W $1491 \mathrm{r}$. Wojciech z Bartochowa uzyskał opiekę nad małoletnimi siostrami swojej żony Doroty z Rzechty i Drużbina, glotibus suis ${ }^{6}$. W księgach sieradzkich występuje jeszcze jeden desygnat nazwy glos. W 1448 r. Jarosław z Cieni wyrazil zgode na zapis oprawy dla Barbary, sue glote alias niewiescze na swych dobrach. Barbara - córka Jana z Wilamowa - byla żoną jego syna Jakuba z Cieni. Najczéściej jednak dla oznaczenia synowej (lac. nurus) stosowano formy opisowe typu: uxor filii, consors filii ${ }^{67}$.

W Sieradzkiem oprócz terminu swak (lac. rivalis, rivalus), oznaczającego męża siostry, jak również męża ciotki, używany był także termin szwagier, przeniesiony z języka niemieckiego. W 1478 r. Zawisza Rakowski - swagerus

\footnotetext{
${ }^{61}$ Ibidem, s. 7.

62 AGAD, KZSz., ks. 3, s. 581; AGAD, KZS, ks. 6, k. 94v.

${ }^{63}$ Slownik lacińsko-polski..., s. 131; AGAD, KZS, ks. 13, k. 112v.

${ }^{64}$ AGAD, KGS, ks. 17, s. 296.

65 Slownik lacińsko-polski..., s. 131.

${ }^{6}$ AGAD, KGS, ks. 27, s. 184; AGAD, KZS, ks. 6, k. 94v - bratowa; M. Szymczak, op. cit., s. $168-180$.

${ }^{67}$ AGAD, KGS, ks. 9, s. 650.
} 
Doroty, żony Jana $\mathrm{z}$ Porszewic, i mąż jej siostry Małgorzaty $\mathrm{z}$ Wlynia - asystowal przy jej oprawie ${ }^{68}$. Warto w tym miejscu zwrócić uwagę, że nazwa rivalus była używana przede wszystkim przez kobiety w stosunku do męża siostry, natomiast gdy nazywającym byl brat siostry, w stosunku do jej męża używano nazwy gener.

Termin gener należał w średniowiecznej lacinie do niezwykle produktywnych. Oprócz klasycznego znaczenia zięć, czyii mąż córki, uzyskał znaczenie męża siostry, w którym zresztą najczęściej wystẹpuje. Dwuznaczność tego terminu doskonale ilustruje zapis dotyczący rodziny Zagórskich. W 1433 r. Jarosław z Zagórzyc nazywa Mikołaja z Lipnicy suo genero, zaś w $1451 \mathrm{r}$. tą samą nazwą określa tegoż Jan z Zagórzyc - syn Jarosława ${ }^{69}$.

Termin gener mógl oznaczać ponadto mężów innych krewnych i powinowatych. W 1446 r. Jan ze Stryi - pleban w Męce - oddał swoje dobra w zarząd Stanisławowi ze Zwiastowic, genero suo, tj. mężowi swej siostrzenicy Katarzyny $^{70}$. W 1471 r. Stanisław Tumigrała - mieszczanin z Warty - z żoną Anną zrzekli się jej części dziedzicznej na rzecz Mikołaja, generi suo germano, tj. brata żony ${ }^{71}$.

Drugą nazwą na określenie brata żony był affinis. W 1430 r. ksiądz Mikołaj - syn Bogusława z Gaci - udając się na studia, przekazal swe dobra w zarząd Mikołajowi z Wysokiego Tądowa, genero suo. W zamian Mikolaj zobowiązał się dawać klerykowi Mikołajowi, affini vulgariter Swachowi, 6 grzywien i 1 wiardunek rocznie ${ }^{72}$.

W ksieggach sieradzkich termin gener występuje ponadto $w$ znaczeniu męża siostry męża ${ }^{73}$.

$\mathrm{Na}$ oznaczenie matki męża język polski odziedziczył z epoki prasłowiańskiej nazwę świekra, zaś matkę żony nazywano ćcia. Wydaje się, że już w XV w. uznaną formą bezpośredniego zwracania się zięcia do teściowej było słowo: mama. Echem tego jest zapiska z 1445 r., w której Piotr z Górki zobowiązal się utrzymywać do końca życia Dzichnę, matrem suam videlicet Thscze, płacąc jej pól grzywny rocznego uposażenia ${ }^{74}$. Piotr był mężem Agnieszki z Rakowic, córki Dzichny, który po spłaceniu drugiej jej córki - Anny (żony Pawła z Warty) - osiadl w dobrach teściów.

${ }^{68}$ Ibidem, ks. 20, s. 200-201.

${ }^{69}$ AGAD, KZS, ks. 10, k. 4; AGAD, KGS, ks. 10, s. 295. W Krakowskiem na oznaczenie zięcia (szwagra?) używano też terminu amicus - Slownik historyczno-geograficzny województwa krakowskiego w średniowieczu, cz. II, z. 3, red. A. Gąsiorowski, Wrocław 1991, s. 367.

70 AGAD, KGS, ks. 8, s. 777; ks. 9, s. 336-337.

71 Ibidem, ks. 17, s. 208.

72 Ibidem, ks. 6, s. 289.

73 Ibidem, ks. 12, s. 363.

74 Ibidem, ks. 8, s. 627-628; por. M. S zy mczak, op. cit., s. 156-160. 
Ostatni przykład potwierdza sformułowaną już w literaturze tezę o jednakowej wadze więzi pokrewieństwa i związków powinowactwa ${ }^{75}$. Wyrazem tego było przenoszenie terminów pokrewienstwa na określenie stosunków powinowactwa. Podobnie jak dzisiaj, dotyczy to przede wszystkim terminu 'wuj'. W 1489 r. Jan z Jedlna h. Nabran zapisal zonie Annie z Rudnik, córce Swiętopelka $h$. Lis, oprawę w obecności Jana z Grabna h. Pomian, podsędka sieradzkiego, avunculum propinquum ab ipsa ${ }^{76}$. Tymczasem Jan z. Grabna był̉ mężem jej ciotki Doroty -- rodzonej siostry jej ojca Świętopełka. Tak samo Jadwiga i Anna - córki Adama $z$ Rembieszowa h. Korab - nazwaly Andrzeja Handę $z$ Bogdanowa h. Doliwa ${ }^{77}$. Był on mężem Katarzyny z Grzymiszewa h. Drya, z którego to rodu pochodziła także ich prababka - Klimka z Tuliszkowa.

Terminologiczną precyzję utrudniały wielokrotne związki małżeńskie, zawierane $w$ kregu krewnych i powinowatych. Przed 1464 r. Jarosław z Remiszewic i jego syn Piotr poślubili siostry: Katarzynę i Elżbietę z Ralewic. W ten sposób Katarzyna stała się macochą męża swej rodzonej siostry! Jan Lisiecki z Morawina byl patruo propinquo dla dzieci Macieja z Kobierzycka i równocześnie dla ich macochy - Katarzyny ${ }^{78}$. W 1474 r. Dorota Grabska - żona Andrzeja $\mathrm{z}$ Żeronic - miała fratrem propinquum Wita z Bartodziei, który byl jednocześnie mężem przyrodniej synowicy Andrzeja ${ }^{79}$.

Wiele relacji genealogicznych pozostanie nie rozpoznanych $\mathrm{z}$ racji ogólności określających je nazw. Nie wiadomo, co łączyło Katarzynę z Górki h. Lodzia - żone Jana Jaranda $\mathrm{z}$ Brudzewa h. Pomian - $\mathrm{z}$ Marcinem Aaronem z Wójcic h. Korab, który określony zostal jako jej amicus propinguus ${ }^{80}$. Możliwe, że ma tu zastosowanie thumaczenie słowa amicus jako szwagier, w sensie męża dalszej krewnej.

W rozważaniach naszych wykorzystališmy przede wszystkim te przypadki określenia więzi pokrewieństwa i związków powinowactwa, w których obok nazwy lacińskiej znalazło się jej polskie thumaczenie. Zdajemy sobie sprawę, że te zestawienia lacińsko-polskie dowodzą w zasadzie wahań pisarzy co do pokrywania się pola semantycznego wyrazów w obu językach. Zasób lacińskich terminów pokrewieństwa i powinowactwa był bowiem uboższy od polskiego. Nie powinno więc dziwić używanie tych samych wyrazów w wielu znaczniach, skąd i potrzeba ich thumaczenia vulgaris. Czy można zatem postawić wniosek, że tam gdzie pisarze posługują się wyłącznie terminami lacińskimi, nie mieli wątpliwości - a tym samym i my nie

\footnotetext{
${ }^{75}$ M. Koczerska, Uwagi..., s. 44-45.

76 AGAD, KGS, ks. 26, s. 48.

77 Ibidem, S. 17.

78 Ibidem, ks. 28, s. 774.

79 Ibidem, ks. 18, s. 301 .

80 Ibidem, ks. 28, s. 909.
} 
powinniśmi ich mieć - co do rodzaju relacji łączących osoby? Nie wydaje się to oczywiste. Rola pisarza była w tym zakresie odtwórcza. Nie można było wymagać od niego wiedzy genealogicznej, obejmującej szlachte $z$ calego powiatu, czy tym bardziej z całego województwa. Te wiedzę musialy posiadać układające się strony, które wyrażały zgodę na udzial poszczególnych członków rodziny $w$ czynnościach prawnych. Teoretycznie -- z racji obowiązującego prawa małżeńskiego - każdy winien znać krąg krewnych do IV. stopnia pokrewieństwa komputacji kanonicznej. W linii prostej znajomość ta jest widoczna i precyzyjna. Natomiast w linii bocznej, poczynając od V. stopnia komputacji rzymskiej, używa się słowa-wytrycha: propinquus. Powoduje to oczywiste problemy identyfikacyjne. Odnotowane wahania terminologiczne mogą być także odbiciem rozbieżności pomiędzy właściwym stopniem pokrewieństwa a używaną na codzień formą zwracania się do danej osoby, co prowadziło do zacierania się znajomości tego pierwszego. Gwarancję poprawnej rekonstrukcji rodzin $w$ średniowiecznej Polsce daje więc nie tylko dobra znajomość terminologii, ale także dobre rozpoznanie środowisk terytorialnych.

4.

affinis - brat żony (szurza)

amicus propinquus - szwagier (?)

amita - siostra matki lub ojca

ava germana - babka

- siostra dziada ojczystego

avunculissa - żona wuja

avunculus amitalis germanus - siostrzenic babki macierzystej

" germanus - wuj, brat matki

$" \quad$ germanus post matrem - wuj

" patruelis germanus - brat stryjeczny matki

" propinquus - mąż siostry ojca

" uterinus - brat przyrodni matki

avus propinquus - brat babki ojczystej lub macierzystej

bratanek - syn brata dla siostry

confraterinus - bratanek, syn brata dla siostry

consobrinus - brat męża dla siostry

ćcia (thscza) - matka żony

dziewierz - brat męża

filiaster - synowiec, syn brata dla brata

- bratanek, syn brata dla siostry

- siostrzeniec, syn siostry

filiastra - synowica, córka brata dla brata

- bratanica, córka brata dla siostry

- siostrzenica, córka siostry 
filiastra patruelis germana - córka brata stryjecznego

frater adnativus - brat przyrodni (po innej matce)

" amitalis, amitabilis - brat cioteczny

" amitalis post matrem - brat cioteczny (po siostrze matki)

" amitalis post patrem - brat cioteczny (po siostrze ojca)

", avuncularis - brat wujeczny

" patruelis - brat stryjeczny

" patruelis ex patruelibus germanus - brat stryjeczno-stryjeczny

" uterinus - brat przyrodni (po innej matce)

fraterinus - bratanek

gener - mąż siostry dla brata

- mąż córki

- mąż siostrzenicy

- brat żony

- mąż siostry męża

glos - siostra żony (świeść)

- siostra męża (zełwa)

- żona brata (jątrew dla siostry, bratowa dla brata)

- żona syna, synowa

levir - brat męża

mater - stara matka, babka

nepos, neptis - wnuk, wnuczka

- bratanek, bratanica

- synowiec, synowica

- siostrzeniec, siostrzenica

- córka siostry żony

niewiasta - żona syna

patruus - stryj, brat ojca

patruus propinquus - brat cioteczny ojca

- brat stryjeczno-stryjeczny ojca

- brat babki ojczystej

privignus - wnuk

- stryj klejnotny

przyrodek - brat $\mathrm{z}$ innej matki

rivalis, rivalus - mąż siostry (dla siostry)

siestrzenica - córka siostry

sororiaster - siostrzeniec

sororinus, sororina - siostrzeniec, siostrzenica

sororinus patruelis germanus - syn siostry stryjecznej

swach, swak - brat żony

- mąż siostry dla brata

swagerus - mąż siostry

świeściszewa - córka siostry żony

uxorinus - brat męża 